\title{
Інноваційні підходи при складанні реабілітаційних програм для пацієнтів з наслідками хребтово- спинномозкової травми
}

\author{
Салєєва А. Д., Чернишова І. М., Нартова І. П., Трегуб Н. Ю., Задерей Н. П. \\ Український науково-дослідний інститут протезування, протезобудування та відновлення \\ працездатності, м. Харків, Україна
}

Актуальність. За даними статистики, щорічно в Україні понад 2500 пацієнтів отримують травми хребта і спинного мозку, $80 \%$ 3 них - пацієнти працездатного віку. Крім проведення медикаментозного лікування, важливе місце в реабілітації цієї категорії пацієнтів займає фізична реабілітація із застосуванням механотерапії, роботизованих систем. Виникає необхідність розробки індивідуальної комплексної реабілітаційної програми 3 урахуванням соматичного стану та результатів тестування для сумісного використання різних методик механотерапії. Програма включала дозоване навантаження та спеціальні реабілітаційні вправи на блочному тренажері, які покращують рухливість суглобів, еластичності м'язів та зв'язок, і застосування роботизованої системи (G-EO) для тренування навиків ходи в стані полегшеної ваги пацієнта.

Метоюдослідженнябулооцінитиефективність розробленої інноваційної програми реабілітації пацієнтів 3 наслідками хребтовоспинномозкової травми.

Матеріали та методи. Під наглядом перебувало дві групи пацієнтів. Хворим першої групи проводилась медикаментозна терапія й апаратна фізіотерапія, пацієнти другої групи отримували медикаментозну терапію, фізіотерапію та механотерапію
3 використанням роботизованої системи G-EO та блочного тренажера. Ефективність проведеного лікування (в середньому 1 місяць) оцінювалась за допомогою Функціональної Оціночної Шкали для хворих з травмою спинного мозку (Vatutazione Fuczionate Mietotesi - VFM), толерантність до фізичних навантажень оцінювалась клінічно (пульс, частота дихання, почервоніння обличчя, запаморочення, підвищене потовиділення).

Результати дослідження та їх обговорення. В результаті проведених досліджень встановлено, що фізична реабілітація сприяла підвищенню толерантності до фізичних навантажень (збільшення часу тренувальних вправ без ознак втоми). Після проведеного курсу реабілітації з використання G-EO та блочного тренажера $80 \%$ пацієнтів (другої групи) мали результати тестування в середньому на 5-10 балів вищі, ніж пацієнти першої групи.

Висновки. Таким чином, за даними проведених досліджень, практика застосування програми комплексної реабілітації 3 використанням роботизованої механотерапії та блочних тренажерів для пацієнтів 3 наслідками спинномозкової травми показала переваги даного підходу.

Ключові слова: програма реабілітації, наслідки хребтово-спинномозкової травми. 